\title{
Decision Support System for Determining the Position of Players in a Football Team Using the Simple Multi At Tribute Rating Technique
}

\author{
Simeon Sergius lyai \\ Faculty of Science and Technology, Universitas Sanata Dharma, Indonesia
}

\begin{tabular}{|c|c|}
\hline ARTICLEINFO & ABSTRACT \\
\hline Article history: & \multirow{4}{*}{$\begin{array}{l}\text { One of the keys to a team's victory in a soccer match is about the } \\
\text { composition of players or the placement of a player's position in } \\
\text { accordance with the abilities he has in the team. In general, the } \\
\text { determination process is carried out manually based on the trainer's } \\
\text { estimates. In this way, it is impossible to know the value of a } \\
\text { formation/team with a certain composition of players. In this study, } \\
\text { the authors create a decision support system that can assist the } \\
\text { coach in determining the most appropriate players to occupy a } \\
\text { position in the team formation. Various assessment factors that } \\
\text { become decision variables in this system will be taken into } \\
\text { consideration in choosing their position. The assessment factors } \\
\text { used are weight (kg), height (m), assessment of tactical assessment } \\
\text { techniques, psychological assessment, physical assessment, } \\
\text { knowledge of a player who is judged when a player makes attacks, } \\
\text { defenses, transitions, scoring per position: goalkeeper, back, center, } \\
\text { front. The author uses the Simple Multi Attribute Rating Technique } \\
\text { (SMART) method because it is considered the most suitable in this } \\
\text { case. By considering various attributes, the value of each player, the } \\
\text { value of the player in a formation, and the value of a team formation } \\
\text { can be obtained with good results. }\end{array}$} \\
\hline $\begin{array}{r}\text { Received Jun 29, } 2021 \\
\text { Revised Jul 12, } 2021 \\
\text { Accepted Jul 27, } 2021\end{array}$ & \\
\hline Keywords: & \\
\hline $\begin{array}{r}\text { Football; } \\
\text { pharmacy; } \\
\text { SMART; } \\
\text { Decision Making System. }\end{array}$ & \\
\hline
\end{tabular}

This is an open access article under the CC BY-NC license.

\begin{abstract}
(c) (i) 8
\section{Corresponding Author:}

Simeon Sergius Iyai

Faculty of Science and Technology, Sanata Dharma University, Indonesia

E-mail: simeonsergius12@gmail.com

\section{INTRODUCTION}

Football is a game that shows the individual's ability to process the ball. Many people around the world love to play and watch football. This activity of watching or playing soccer becomes an activity to unwind from various tasks at the office, campus, and so on. In addition, this activity can also be an activity to strengthen kinship relations. Football fans often have favorite players, clubs and national teams.

A club certainly wants to win and win various tournaments. There are various keys to a team's victory, for example the composition of players, the foresight of the coach, the selection of formations, the individual abilities of the players, and so on. All these keys are fulfilled by the club through routine training activities that are neatly arranged starting from basic exercises such as dribbling, passing, shooting and so on, including teamwork. In general, a player is considered good if the player can play in several positions or in other words more than one position. This condition allows a player to rotate in any situation according to the scheme provided by the coach. In the
\end{abstract}


Sanata Dharma University (USD FC) soccer UKM, there were several obstacles experienced by the team, coaches, and management,

USD FC, the name for the Sanata dharma Student Activity Unit team in the Yogyakarta city PSSI branch competition is registered with the Yogyakarta City Civil Service PSSI so that they often participate in competitions held by the Yogyakarta City PSSI branch. The Yogyakarta City PSSI branch consists of two divisions, namely Division 1 and the Main Division. In 2015 USD FC was still in Division 1. To be able to move up to the First Division, USD FC needed players who had good individual abilities. However, USD FC has many obstacles such as players often not being on time, training schedules clash with class schedules so that players do not attend training regularly. This obstacle causes players not to develop quickly and coaches find it difficult to review the development of each player's abilities and then save them into a file that will become the coach's archive.

Another problem also often occurs between players who practice often and players who rarely practice. Some players who practice often are rarely called upon to defend the USD FC team in participating in competitions, which can lead to jealousy between players. The absence of players in training due to conflicts with the class schedule so that they can still be tolerated to be included in the team.

The various obstacles above cause the player's assessment file to become very large or the record may be incomplete, so the coach will be confused in determining the most suitable player positions and alternative player positions according to the abilities of the players. Another major obstacle is choosing substitute players if the main players cannot be played with various obstacles, for example colliding with the exam schedule, assignments from campus, unfit health and so on.

From some of the problems above, the writer took the initiative to make a final project with the title "Support System for Decision Making in Determining the Position of Players in a Football Team Using the Modified Simple Multi Attribute Rating Technique (SMART) Method. Case Study: USD Soccer UKM (Universitas Sanata Dharma Yogyakarta)" to be able to assist coaches in solving these problems. Through this system, the coach can clearly see which players are suitable to occupy certain positions as well as alternative positions of these players according to the abilities possessed by a player.

\section{METHOD}

The methods used in order to answer these problems in this study are as follows:

a. Problem analysis

At this stage, analyze the problem by conducting interviews, archive studies and literature studies. Interviews were used to collect information about data on soccer players. Archival studies were carried out to study documents related to player data ranging from player abilities, player development during the training provided by the coach. The analysis of the problem is also supported by a literature study that is used to find patterns for decision making.

b. System Development

The model that will be used is the waterfall model. Where the waterfall model is a sequential software development process, through phases such as planning, modeling, implementation (construction), testing and maintenance.

c. System Effectiveness Testing

This stage serves to test the effectiveness of the decision-making support system for positioning the soccer team in making decisions. The testing process itself will be tested directly to the user, after that the user will fill out a questionnaire about the effectiveness of the system being built.

d. Data analysis

The data obtained will be calculated using a Likert scale. Calculations will be calculated for each item of the questionnaire.

e. Withdrawal of Conclusion

Based on the results of data analysis that has been carried out in the previous stage, conclusions can be drawn from this research. The use of a decision support system for 
determining the position of players in a soccer team can be said to be effective if many of the statements contained in the questionnaire can be received well or very well.

\section{RESULTS AND DISCUSSIONS}

1. System Test

System testing can be done in two ways, first by testing or comparing manual calculations (Ms Excel) with calculations from the application and the second is analyzing the results of questionnaires from users. The following is a test of the system.

2. Excel

The following is a comparison of the results between manual calculations (Ms Excel) and the application. This is a manual test.

a. Player Data

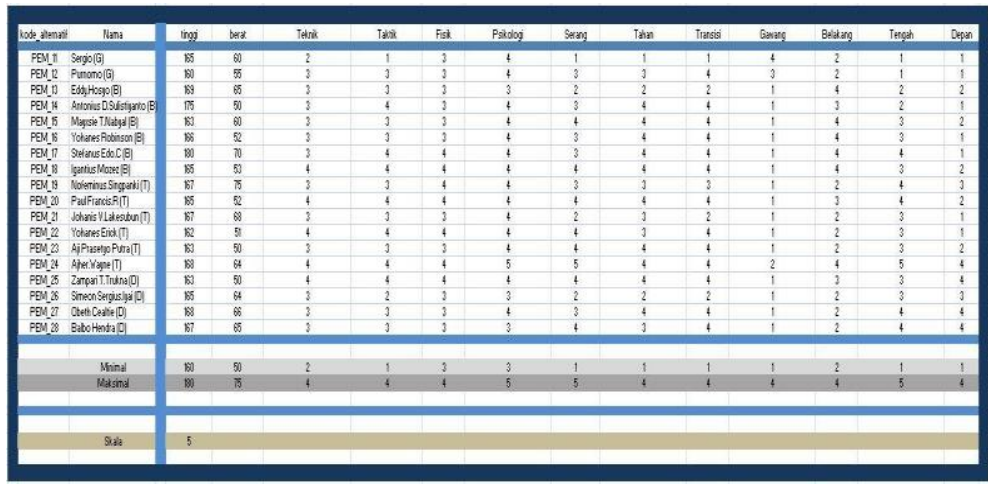

Figure 3 Player Data

b. Goal Factor Weight and Objective Factor Weight Normalization

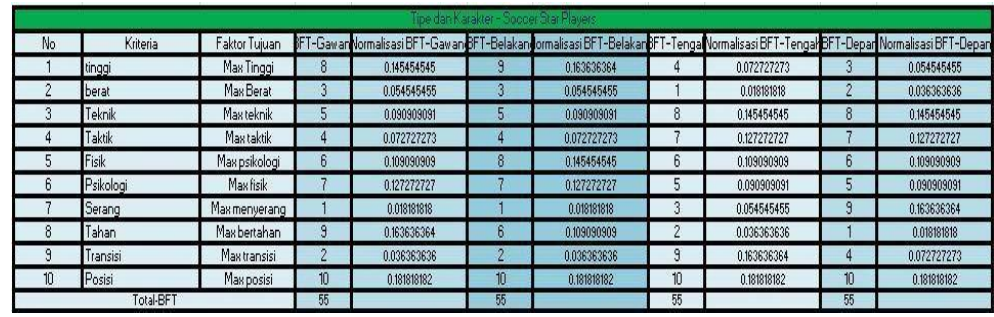

Figure 4 Goal Factor Weights and Normalization per position

c. Criteria Interval Value

\begin{tabular}{|c|c|c|c|c|c|c|c|}
\hline \multicolumn{8}{|c|}{ Tipe dan Karakter - Soccer Star Players } \\
\hline \multirow{2}{*}{ No } & \multirow{2}{*}{ Kriteria } & \multirow{2}{*}{ Interval } & \multicolumn{5}{|c|}{ Interval } \\
\hline & & & 1 & 2 & 3 & 4 & 5 \\
\hline 1 & tinggi & 4 & $x=160 \& \&<164$ & $x=164 \& \&<168$ & $x=168 \& \&<172$ & $x=172 \& \&<176$ & $x=176 \& \&=<180$ \\
\hline 2 & berat & 5 & $>=50 \& \&<55$ & $>=55 \& \&<60$ & $s=60 \& \&<65$ & $y=65 \& \&<70$ & $x=70$ \& \& $=>75$ \\
\hline 3 & Teknik & 0.4 & $x=2 \& \&<2.4$ & $x=2.4 \& \&<2.8$ & $\Rightarrow=2.8 \& \&<3.2$ & $y=3.2 \& \&<3.6$ & $x=3.6 \& \&=<4$ \\
\hline$\overline{4}$ & Taktik & 0.6 & $>=1 \& \&<1.6$ & $x=1.6 \& \&<2.2$ & $x=2.2 \& \&<2.8$ & $x=2.8 \& \&<3.4$ & $x=3.4 \& \&=<4$ \\
\hline 5 & Fisik & 0.2 & $x=3 \& \&<3.2$ & $x=3.2 \& \&<3.4$ & $x=3.4 \& \& 3.6$ & $x=3.6 \& \&<3.8$ & $x=3.8 \& \&=x 4$ \\
\hline 6 & Psikologi & 0.4 & $x=3 \& \&<.4$ & $p=3.4 \& \&<3.8$ & $x=3.8 \& \&<4.2$ & $x=4.2 \& \&<4.6$ & $x=4.68 \&=<5$ \\
\hline 7 & Serang & 0.8 & $x=1 \& \&<1.8$ & $x=1.8 \& \&<2.6$ & $s=2.6 \& \& 3.4$ & $x=3.4 \& \&<4.2$ & $x=4.28 \&=x 5$ \\
\hline 8 & Tahan & 0.6 & $\gamma=1 \& \&<1.6$ & $x=1.6 \& \&<2.2$ & $r=2.2 \& \&<2.8$ & $y=2.8 \& \&<3.4$ & $x=3.4 \& \&=<4$ \\
\hline 9 & Transisi & 0.6 & $x=1 \& \&<1.6$ & $x=1.6 \& \&<2.2$ & $\Rightarrow=2.2 \& \& \& 2.8$ & $y=2.8 \& \&<3.4$ & $x=3.4 \& \&=<4$ \\
\hline 10 & Gawang & 0.6 & $x=1 \& \&<1.6$ & $x=1.6 \& \&<2.2$ & $x=2.2 \& \&<2.8$ & $x=2.8 \& \&<.4$ & $x=3.48 \&=<4$ \\
\hline 11 & Belakang & 0.4 & $x=2 \& \&<2.4$ & $x=2.4 \& \&<2.8$ & $x=2.8 \& \& 3.2$ & $x=3.28 \&<3.6$ & $x=3.68 \&=44$ \\
\hline 12 & Tengah & 0.8 & $>=1 \& \&<1.8$ & $p=1.8 \& \&<2.6$ & $\Rightarrow=2.6 \& \& 3.4$ & $x=3.4 \& \&<4.2$ & $>=4.2 \& \&=<5$ \\
\hline 13 & Depan & 0.6 & $>=1 \& \&<1.6$ & $x=1.6 \& \&<2.2$ & $x=2.2 \& \&<2.8$ & $x=2.8 \& \&<3.4$ & $x=3.4 \& \&=<4$ \\
\hline
\end{tabular}

Figure 3 Criteria Interval Value

d. Normalization of Criteria Value 


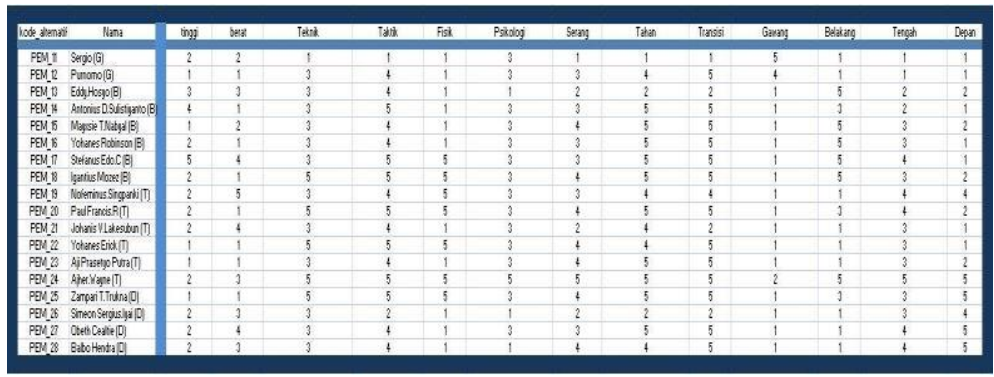

Figure 4 Normalization of Criteria Value

e. Utility Score

\begin{tabular}{|l|c|c|c|c|c|}
\hline nilaibobot & 1 & 2 & 3 & 4 & 5 \\
\hline Normalisasi & 0 & 0.25 & 0.5 & 0.75 & 1 \\
\hline
\end{tabular}

Figure 5 Utility Score

f. Convert Normalized Value to utility Score

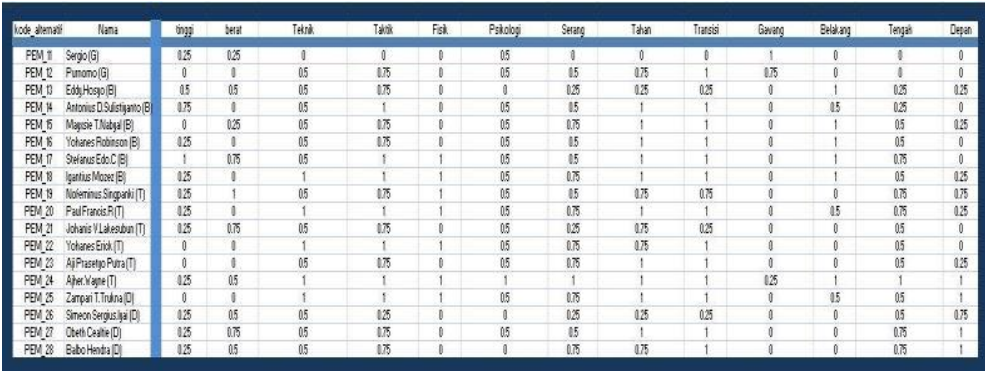

Figure 6 Convert Normalized Value to Utility Score

g. Final score

\begin{tabular}{|c|c|c|c|c|c|}
\hline kode_alternatif & Nama & Gawang & Belakang & Tengah & Depan \\
\hline PEM_11 & Sergio (G] & 0.2955 & 0.1182 & 0.0682 & 0.0682 \\
\hline PEM_12 & Purnomo(G) & 0.4682 & 0.2909 & 0.4318 & 0.3818 \\
\hline PEM_13 & Eddy.Hosyo (B) & 0.2545 & 0.4318 & 0.3227 & 0.3227 \\
\hline PEM_14 & Antonius D. Sulistiyanto $(B)$ & 0.5000 & 0.5500 & 0.5727 & 0.4591 \\
\hline PEM_15 & Mayysie T.Nabyal (B) & 0.3909 & 0.5182 & 0.5500 & 0.4818 \\
\hline PEM_-16 & Yohanes Robinson (B) & 0.4091 & 0.5409 & 0.5500 & 0.4000 \\
\hline PEM_17 & Stefanus Edo.C (B) & 0.6864 & 0.8682 & 0.8045 & 0.6091 \\
\hline PEM_18 & Igantius Mozez (B) & 0.5864 & 0.7545 & 0.7773 & 0.7000 \\
\hline PEM_19 & Nofeminus.Singpanki (T) & 0.5227 & 0.5227 & 0.6727 & 0.6591 \\
\hline PEM_20 & Paul Francis.R(T) & 0.5864 & 0.6636 & 0.8227 & 0.7000 \\
\hline PEM_21 & Johanis V.Lakesubun (T) & 0.3773 & 0.3409 & 0.4182 & 0.3273 \\
\hline PEM_22 & Yohanes Erick (T) & 0.5091 & 0.5045 & 0.7500 & 0.6364 \\
\hline PEM_23 & A.ji Prasetyo Putra (T) & 0.3773 & 0.3227 & 0.5455 & 0.4727 \\
\hline PEM_24 & Ainer.Wayne (T) & 0.7273 & 0.8500 & 0.9364 & 0.9409 \\
\hline PEM_25 & Zampari T.Trukna (D) & 0.5500 & 0.6227 & 0.7591 & 0.8227 \\
\hline PEM_26 & Simeon Sergius.lyai (D) & 0.1818 & 0.1727 & 0.2864 & 0.3364 \\
\hline PEM_27 & Obeth Cealtie (D) & 0.4500 & 0.4000 & 0.6091 & 0.6091 \\
\hline PEM_28 & Balbo Hendra (D) & 0.3364 & 0.3000 & 0.5636 & 0.5909 \\
\hline
\end{tabular}

3. System

Figure 7 Final score

This is a test with the system: 
a. Goal Factor Weight

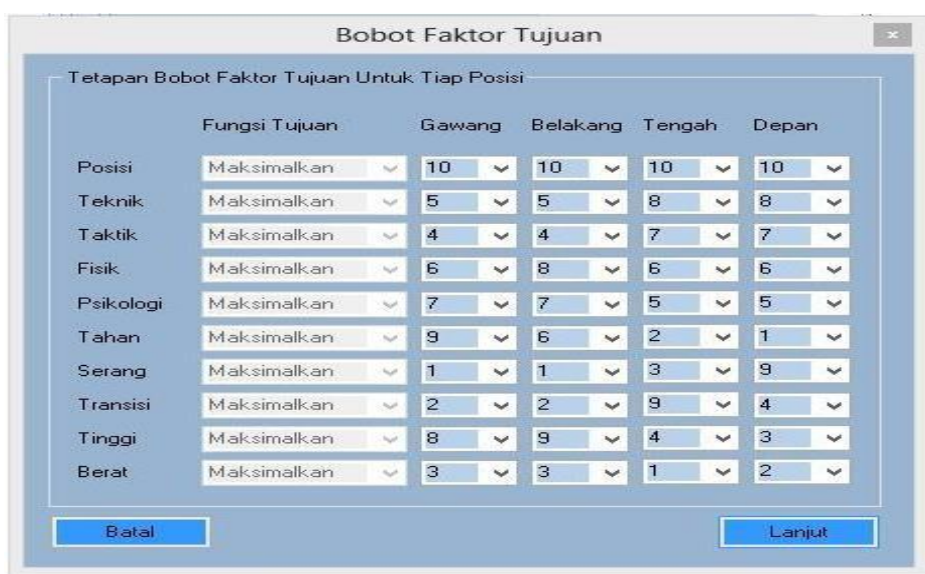

Figure 8 Goal Factor Weight per Position

b. Normalization of Goal Factor Weight

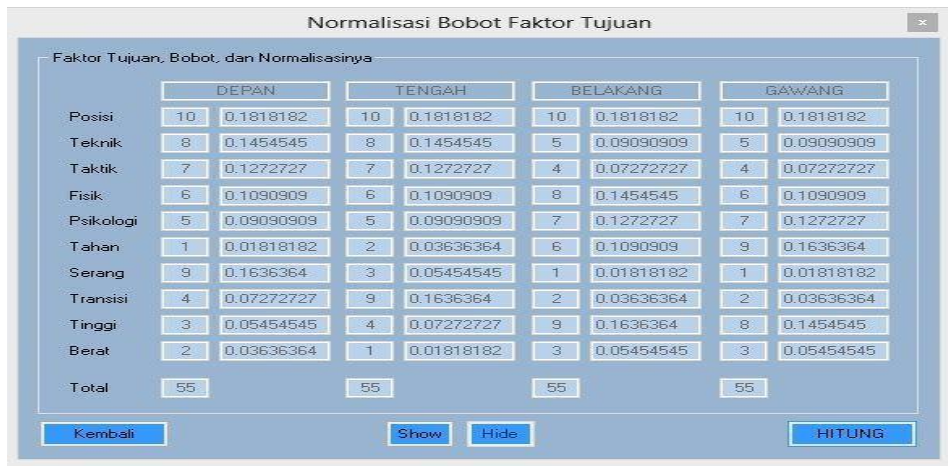

Figure 9 Normalization of Goal Factor Weights per Position

c. Final score

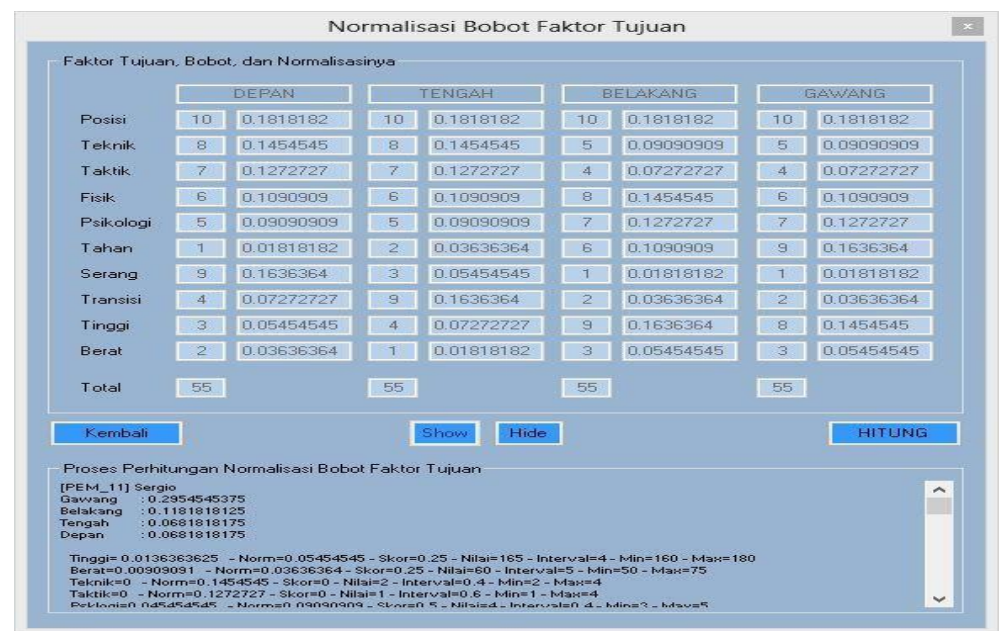

Figure 10 Final Score Hasil 
In this section is a description of the answers to the system evaluation questionnaire given to users. The questionnaire is divided into three biggest aspects, namely the Aspects of Purpose and Benefits, Functional Aspects and Non-Functional Aspects with several questions. Following are the results of the system evaluation questionnaire:

Aspects of Purpose and Benefits

a. Statement : The system is able to support decision making in determining the position of soccer players according to the ability of the players User Response : Strongly Agree

b. Statement : With this system the positioning process becomes more effective

\section{CONCLUSION}

The conclusions obtained from the research on making a decision support system for determining the position of soccer players are as follows: The Decision Support System for Positioning Players in a Football Team has been successfully built using the SMART (Simple Multy Attribute Rating Technology) method and the C\# programming language. (C Sharp). This system can determine the best position of a player as well as alternative positions. The Decision Support System for Determining the Position of Football Players using the SMART (Simple Multy Attribute Rating Technology) method can assist the coach in determining the position of a player effectively according to the ability of the player. The calculation results of the SMART method for determining the position of this player in the application are the same as the results of the manual calculation.

\section{References}

Daihani Dadan Umar, 2001. Komputerisasi Pengambilan Keputusan. Jakarta : Penerbit PT Elex Media Komputindo.

Kusrini, 2007. Konsep dan Aplikasi Sistem Pendukung Keputusan. Yogyakarta : Penerbit Andi.

Turban, Efraim, 1995. Decision Support Systems and Expert System. New York : Prentice-Hall.

Widhiyanta, Antonius Krisna, 2013. SISTEM PENDUKUNG PENGAMBILAN KEPUTUSA

PEMILIHAN SEPEDA MOTOR DENGAN METODE SMART. Yogyakarta: Skripsi USD.

Docherty, Tommy. 1978. The ABC of Soccer Sense Strategy \& Tactics today.

London: The Anchor Press Ltd,

Bangsbo, Jens dan Peitersen, Birger. 2008. Soccer Systems \& Strategies. United States: Human Kinetics

Bridle, Bob, dkk. 2011. Essential Soccer Skills. Newe York: Dorling Kindersley Dooley, Thomas dan Titz, Christian. 2011. Soccer-The 4-4-2 System. United

Kingdom: Meyer \& Meyer Sport

Scheunemann, Timo. 2008. Dasar-dasar Sepak Bola Modern Untuk Pemain dan Pelatih. Malang: Dioma Nugroho, Robertus Adi, S.T., M.Eng. (2013). Materi kuliah Pengantar Pemrograman .NET dan Praktikum Pengantar Pemrograman .NET, Jurusan Teknik Informatika Universitas Sanata Dharma, Yogyakarta 